\title{
Strategic Voting in Slovak Regional Elections of 2013 and 2017: Evidence for Duverger's Law in Elections of Presidents of Regional Self-Government?
}

\author{
Pavel Maškarinec ${ }^{1}$ \\ Department of Political Science and Philosophy, Faculty of Arts, Jan \\ Evangelista Purkyně University, Ústí nad Labem
}

\begin{abstract}
Strategic Voting in Slovak Regional Elections of 2013 and 2017: Evidence for Duverger's Law in Elections of Presidents of Regional Self-Government? This article tests Duverger's law through an analysis of the 2017 elections of Slovakian regional presidents which were held under the new first-past-the-post (or single-member plurality) system, and comparison with results of the previous election of 2013 which used a tworound system (absolute majority run-off). The main aim of the article is to test the expectations of strategic voting in the context of the so-called second-order elections, under which regional elections can be classified. The results show that strategic voting was not a universal phenomenon under the plurality rule in 2017, as indicated by electoral results and party competition at the level of electoral precincts. In most electoral precincts, the character of electoral competition was not in compliance with theoretical expectations and two-party competition. More importantly, the introduction of FPTP, instead of TRS, should lead to increasing two-party competition and strategic voting, but the opposite was true. Competition at precinct level in 2017 went far away from the Duvergerian equilibrium, as two-party competition increased in only one out of eight regions, Trnava, compared to 2013. Finally, segmented Nagayama diagrams likely proved as the most suitable indicator of competitiveness and strategic behaviour, helping us identify the patterns, but above all, changes to the patterns, of electoral competitiveness between elections. Our research thus confirmed that the effect of electoral institutions (institutional structure) is contingent upon and (at the district, or precinct, level) inhibited by country-specific conditions, with potentially strong influence of the second-order character of the Slovak regional elections. Sociológia 2018, Vol. 50 (No. 6: 697-726) https://doi.org/10.31577/sociologia.2018.50.6.26
\end{abstract}

Key words: Slovakia; regional elections; presidents of regional parliaments; secondorder elections; electoral competition; first-past-the-post; strategic voting; Duverger's law

\section{Introduction}

On 24 March 2017, Slovakian parliament (National Council of the Slovak Republic) had overridden a veto of Slovakian president Andrej Kiska and definitively adopted a new first-past-the-post (FPTP), or single-member plurality (SMP) system, for election of presidents of the self-governing regions (regional parliaments), leaving its current majority-runoff two-round system (TRS) behind ${ }^{2}$. After almost sixteen years and four regional elections, thus, Slovakian voters lost the opportunity to vote "sincerely", which is often

\footnotetext{
1 Address: Mgr. Pavel Maškarinec, Ph.D., Department of Political Science and Philosophy, Faculty of Arts, Jan Evangelista Purkyně University, Pasteurova 3571/13, 40096 Ústí nad Labem, Czech Republic. E-mail: maskarinec@ centrum.cz

2 For more on the development of Slovakian self-governing regions, see Klimovský (2006), Buček (2011)
} 
mentioned as one of the advantages of the two-round system. (Blais 2004: 93) Moreover, according to Duverger's (1954) famous conception, they were faced with a new choice to vote strategically or else risk wasting their votes when selecting the highest-ranking person of their regional self-government.

For that reason, the recent Slovakian case is very useful for testing Duverger's expectations in the context of electoral reform. At the same time, recent empirical research on voting in single-member districts (SMDs) based on extensive datasets of election results demonstrated the general (although not perfect) validity of Duverger's law (1954), i.e., that the average outcome under plurality rule is generally consistent with two-party competition. Another reason to analyse the regional electoral contest is that Slovak regional elections have not yet been subject to wider research interest. Few authors concentrated on all Slovakian regions (Krivý 2002, 2006; Benkovičová 2006; Spáč et al. 2016; Plešivčák 2017; Kováčová 2018; Marušiak 2018), whereas others focused only on electoral behaviour in specific regions. (Dolný 2014; Gregor 2015; Hrušovský 2015; Mikuš et al. 2016; Buček - Plešivčák 2017) Finally, as regional elections can be seen as second-order elections (Reif - Schmitt 1980; Schakel 2015), it is important to verify the assumptions of strategic voting, as well as Duverger's theory, also in elections of presidents of Slovakian regions (as second-order institutions), because some studies analysing voters' strategic behaviour in the post-communist space (focused just on strategic voting in second-order elections) found significant inconsistencies to Duverger's assumption, whether it was local elections in Romania held under the proportional system (Albescu et al. 2012), or elections to the upper chambers of parliaments in the Czech Republic using the TRS (Hájek 2015) and Poland with the FPTP, respectively. (Maškarinec 2016) ${ }^{3}$

This article tests the effects of FPTP in the 2017 elections of regional presidents by analysing precinct-level results, i.e. results at the lowest possible level of aggregation. Especially, we address the question whether the electoral competition at precinct level was consistent with Duverger's law (two-party competition) as well as the extent to which voter behaviour and the prevalence of strategic voting changed from the last elections under the TRS in $2013 .{ }^{4}$ The format of this analysis is as follows. First, we briefly review the existing formal literature on Duverger's law. In the second part, the methods of analysis are

\footnotetext{
3 A similar conclusion can be formulated even for the national level in post-communist countries. For instance, neither did the 2008 electoral reform for both chambers of the Romanian parliament completely confirm the expected influence of electoral change, i.e. that political institutions matter. In fact, a process of dealignment hindered the full effect of electoral institutions. (See Feşnic - Armeanu 2014) Even in post-communist Mongolia, which used TRS (although a non-majoritarian one) between 1996 - 2004, the emergence of bipolar party politics was not an immediate process (it was completed only over a series of elections) and nor did the introduction of FPTP in 2016 result in electoral outcomes in full compliance with Duverger's law and the bipolar form of electoral politics. (See Maškarinec 2017, 2018b)

4 For more details on the results of the 2017 regional elections in Slovakia, see, for instance, Kováčová (2018), Marušiak (2018).
} 
introduced. In the third part, the analysis of strategic voting is presented. The concluding section formulates some implications of the results for further research.

\section{Theoretical framework: 'micro-Duvergerian' agenda and strategic voting}

The importance of Duverger's (1954) seminal work, Political Parties, lies in highlighting the possibility to predict relationships between electoral system and political outcomes (Taagepera 2007: 101), although Riker (1982: 754-760) and Benoit (2006: 70-71) pointed to the fact that Duverger was not the first author to discover that simple plurality electoral systems have a tendency to result in two-party systems. This research area was later called 'Duvergerian agenda' by Shugart (2005: 28) who further emphasized its role in forming the core of the field of electoral studies during the 1990s.

Historically, both Duverger's law and his hypothesis have been in the centre of electoral research ${ }^{5}$. However, until the 1990s, most empirical studies focused primarily on the national level ('macro-Duvergerian agenda'), although the district level ('micro-Duvergerian agenda') is the most appropriate level for testing Duverger's assumptions. (cf. Shugart 2005: 30-32; Taagepera 2007: 101-114) Since the 1990s, a number of studies have attempted to test Duverger's law at the district level. Considerable attention has been given especially to the effects of electoral rules in SMD contests, as most authors dealing with the size of party systems see district magnitude (the number of seats that a particular district has in the parliament) as a major determinant of the number of political parties in a polity. (Rae 1971; Riker 1982; Taagepera Shugart 1989)

Duverger's (1954) assumption that plurality rule can create a two-party competition is based on two underlying effects ('mechanical' and 'psychological') which create incentives for voters and candidates to act strategically. (Duverger 1954) While the mechanical effect concerns how votes are translated into seats, the psychological effect consists of candidates' and voters' response to the workings of the mechanical effect. (cf. Benoit 2006: 7476)

The Duvergerian logic assumes that voters are short-term instrumentally rational, concerned only about affecting the outcome of the current election. (Singer 2013: 203) Strategic voting is then indicated by the presence of voters who desert their preferred (small) parties (candidates) if they have only limited chances to gain a seat (as a reaction of political actors to the expected effects of

\footnotetext{
5 While Duverger's law predicts that 'the simple-majority single-ballot system favours the two-party system' (Duverger 1954: 217), his hypothesis claims that 'both the simple-majority system with second ballot and proportional representation favour multi-partism'. (Duverger 1954: 239)
} 
electoral rules, i.e. the workings of a mechanical factor), in favour of less preferred parties (candidates) with real chances to succeed. Similarly, parties can act strategically by not nominating candidates (or by joining other parties or coalitions) in the districts where they traditionally have only limited support, with deterring potential for new entrants to join the race. It is then possible to describe Duverger's law as an equilibrium that is reached only over a series of elections. (Gaines 1999: 837; Benoit 2006: 74-76) In repeated elections, provided that all voters and parties act perfectly strategically, the equilibrium will emerge when only two candidates receive all the votes and the votes obtained by the third and following candidates approximate zero.

Some empirical studies (Gaines 1999; Diwakar 2007; Chytilek 2007; Grofman et al. 2009; Dunleavy - Diwakar 2011) found various violations of the Duvergerian assumptions at the level of individual countries (e.g., India, Canada, UK, USA). However, a recent analysis working with large data sets of elections in SMDs confirmed that district magnitude had (at the district level) the effect that Duverger had expected, although the effect of electoral institutions could be contingent on and (at the district level) inhibited by country-specific conditions such as social cleavages that generate demand for additional parties. (Singer - Stephenson 2009: 481) For instance, Singer found that the average outcome under plurality rule is generally, although not perfectly, consistent with two-party competition. The two largest parties (candidates) typically dominate the districts, but third-place parties (candidates) do not entirely disappear, and ethnic divisions shape party fragmentation even under plurality rule. (Singer 2013: 201) Clark and Golder, who analysed the underlying causal process by which sociological and institutional factors shaped party systems, then concluded that Duverger was right about the determinants of party systems, as plurality rule systems acted as a 'brake' on the process by which societal pressures translate into a growth or a decline in the number of political parties. (Clark - Golder 2006: 706) Finally, Raymond (2015), in his analysis of West European elections prior to the adoption of proportional representation, confirmed Clark and Golder's finding about the importance of the 'social cleavage explanation'. Here, occupational diversification, or the emergence of a class cleavage, respectively, was positively associated with an increase in mean district-level party system fragmentation, eventually leading (given the presence of higher levels of social cleavage diversity) to violation of the two-party assumption associated with the anticipated effect of Duverger's law. (cf. Raymond 2015: 2-5) Generally, although some studies have found rather mixed results, an important fact in this context is that even Duverger (1954: 228) did not consider his proposition as absolutely valid, but rather as a possible tendency which may be influenced by other factors. 
Cox (1997) formulates three conditions for strategic voting to potentially lead to bipartism: 1) short-term instrumentally rational voters; 2) reasonably accurate and publicly available information on candidate standings; 3) myopic ('price-taking') adjustment. Here, one very important aspect is that without knowing different candidates' preferences, voters are unable to make a plausible judgment as to which one of the top two 'losers' in a race (secondand third-place candidates in plurality vote) is the principal challenger, and who should obtain their strategic vote. (Cox 1997: 79) As a result, supporters of the third-place candidate will face little incentive to cast their vote elsewhere, which leads to a non-Duvergerian equilibrium.

However, the assumption of voter rationality was questioned by Reed (1990: 335-336) who pointed to the dubious psychological foundations of the assumption of short-term instrumental rationality, namely that voters will correctly analyse the situation and maximize their self-interest. In this context, the models grounded in a Downsian (1957) approach, where political competition is based on a single dimension, are quite often in conformity with Duverger's expectations. (Grofman et al. 2009: 4) According to Downs, a rational voter decides with regard to 'sophisticated' voting (Downs 1957: 48), which means that the voter does not vote for his preferred alternative, but for an alternative ensuring the best realizable outcomes, after considering anticipated votes by other voters. (Riker 1982: 792) In the Downsian perspective, the process of voting (or candidate selection) takes place as part of the 'selection process', rather than an 'expression of preference'. (Riker 1982: 764) Nevertheless, Reed stressed that voters' rational decisions are limited as party preferences are typically known at a national, rather than district level; learning, rather than rationality, then connects structure and behaviour. (Reed 1990: 336)

Furthermore, Grofman, Blais and Bowler (2009: 4) emphasized that the logic underlying Duverger's law contrasts with Grofman's (1999: X-XI) 'embeddedness effects', i.e. an assumption that electoral rule (institutional structure) is embedded in a wider political system that provides its own set of incentives. For instance, Crisp et al. (2012), who analysed effects of electoral contexts on the degree of coordination failure (i.e. wasted votes at district level), found that new electoral rules, the entry of new parties, electoral volatility and high district magnitudes are all likely to increase voters' coordination failure and undermine their ability to act strategically. Furthermore, Tavits and Annus emphasized the role of democratic experience in new democracies of Central and Eastern Europe, where strategic voting increases as voters and political elites become more experienced with the electoral process - the so-called 'learning hypothesis'. (cf. Tavits - Annus 
2006: $80-87)^{6}$ Similarly, Raymond et al. showed that the effects of electoral systems and social cleavages significantly differ between emerging and established democracies, although the gap narrows with consecutive elections in new democracies. (cf. Raymond et al. 2016: 556-562)

Nevertheless, even Duverger's original work assumed that the electoral system is not the only (exclusive) determinant of the number of parties. More importantly, Clark and Golder (2006: 680) emphasized that in spite of being referred to as the father of the so-called institutionalist approach, Duverger clearly described the way in which social and institutional variables interact. However, many researchers often ignore his argument that the number of political parties is not determined primarily by electoral systems (institutional structure) but by socioeconomic factors (social structure). It is for this reason that Duverger (1954: 235) describes the effect of electoral systems metaphorically as that of 'a brake or an accelerator' which hinders or facilitates growth in the number of political parties, but considers socioeconomic factors as the decisive 'driving power' of a country's party system.

Finally, although electoral rules (institutional structure) play an important role for Duverger, it is rather social heterogeneity (social structure) which is the primary driving force behind the multiplication of political parties. Novák (cf. 2015: 26-33) refers to Duverger's conception as a sociological-institutionalist approach, but emphasizes that the 'secondary' position of institutional structure does not mean that its role in shaping the party system is insignificant, while Clark and Golder (2006: 704) claim that electoral arrangements then only act as a modifier, translating the effect of social forces into the exact number of parties.

\section{Data and methods}

The basic data for this analysis consist of district- or, more precisely, precinctlevel results of the 2013 and 2017 regional elections in Slovakia as collected by the Statistical Office of the Slovak Republic. Because of the above-mentioned problems, we take different approaches to studying the extent of strategic voting at the level of 5932 (2013) or 5968 (2017) Slovakian precincts, as well as the psychological mechanism implied by Duverger, within the framework of the 'micro-Duvergerian' agenda.

First, we analyse the character of electoral competition at the micro level. As simply the percentage of the vote obtained by the top two (parties') candidates may create a misleading picture of the size of the party system, we

\footnotetext{
${ }^{6}$ Charvát (2009: 103-105) claims that the results of electoral reform in new democracies of Central and Eastern Europe contradict Duverger's expectations, with more fragmented party systems in countries using SMDs compared to countries using proportional systems. Specifically, this can be documented on the Hungarian case. (cf. Nikolenyi 2004; Kiss 2015; Maškarinec 2018a)
} 
use a measure which weighs parties according to their relative sizes. Specifically, we calculate Laakso and Taagepera's (1979) effective number of electoral parties $(E N E P)$ in each precinct as a measure of strategic voting. According to Duverger's theory, plurality rule should lead to two-party competition, with an effective number of parties (candidates) of approximately two, while majoritarian rule should produce a larger effective number of parties. However, as the ENEP produces various values of fragmentation, Taagepera (2007: 103) argues that districts with the ENEP ranging between 1.5 and 2.5 are consistent with Duverger's law. Similarly, Chhibber and Kollman (2004: 48) use the value of 2.5 as the threshold, with districts where ENEP is greater than 2.5 violating Duverger's law.

Second, we use Cox's (1997) Second-First Loser ratio, 'SF-ratio' (the vote share secured by the second loser in relation to the votes secured by the first loser). The $S F$-ratio is particularly useful as one of the possible ways of operationalizing Duverger's theory and as it offers a detailed insight into the electoral behaviour at the lowest level of aggregation, including any instances of strategic voting (or the degree of tactical voting) across SMDs. (Singer 2013: 209-210) Similarly, the $S F$-ratio helps us indicate various degrees of strategic defection from less competitive to more competitive candidates across SMDs. (Moser - Scheiner 2009: 51) An SF-ratio near 0 signifies a Duvergerian equilibrium (the first loser is way ahead of the second loser), while the value of 1 shows a non-Duvergerian equilibrium where voters are unable to coordinate their electoral behaviour, leaving the two losers nearly tied. In other words, as it becomes clear who the top challenger in a SMD will be, voters become much less likely to continue to support the candidates who are expected to run third or worse. As a result, the second-ranking candidate will have many more votes than the third-ranking candidate in the district. In contrast, if voters are either unwilling or unable to cast strategic ballots, the $S F$-ratios will tend to be higher.

However, using the $S F$-ratio is not free of potential shortcomings. First, looking at $S F$-ratios does not enable us to exactly differentiate between $S F$ ratio distributions, especially ones that are very similar. Second, $S F$-ratio values can be ambiguous for several reasons: for instance, when both the second and the third losers are considered potentially strong candidates and, therefore, neither of them is abandoned by voters, or when both are truly minor candidates and neither of them receives many votes. Third, $S F$-ratios themselves cannot identify who the key actors are. Fourth, the $S F$-ratio does not account for deviations from a two-party competition in which multiple small parties combine to capture significant portions of the vote ${ }^{7}$. Finally, there

\footnotetext{
${ }^{7}$ For a detailed discussion regarding possible distortion of the results by using the $S F$-ratio, see Moser and Scheiner (2012; online appendix).
} 
is an ecological inference problem when aggregated data are used at all. (cf. Cox 2001: 237; Moser - Scheiner 2009: 51; Singer 2013: 210) ${ }^{8}$

For these reasons, we also used segmented Nagayama diagrams to understand the nature of competitiveness at the district (precinct) level ${ }^{9}$. The main advent age of the Nagayama diagrams is that they can visually (i.e. more intuitively than other methods) display and compare electoral outcomes for the degree of competition between the most successful parties (candidates), and the extent to which smaller parties (candidates) get a substantial share of votes. (Reed 2001; Taagepera 2004) In an effort to express in detail the characteristics of electoral competition, Grofman et al. (2004) divide the Nagayama diagram into eight segments that reflect the relative strengths of the first-, second- and lower-ranking parties (candidates). While the percentage of results in segments $\mathrm{A}, \mathrm{B}$ and $\mathrm{C}$ (see Figure 1) can be taken as indicating bipolarized results, the proportion of districts in segments $\mathrm{F}, \mathrm{G}$ and $\mathrm{H}$ indicates multiparty results ${ }^{10}$.

\section{Figure 1: Segmented Nagayama diagram}

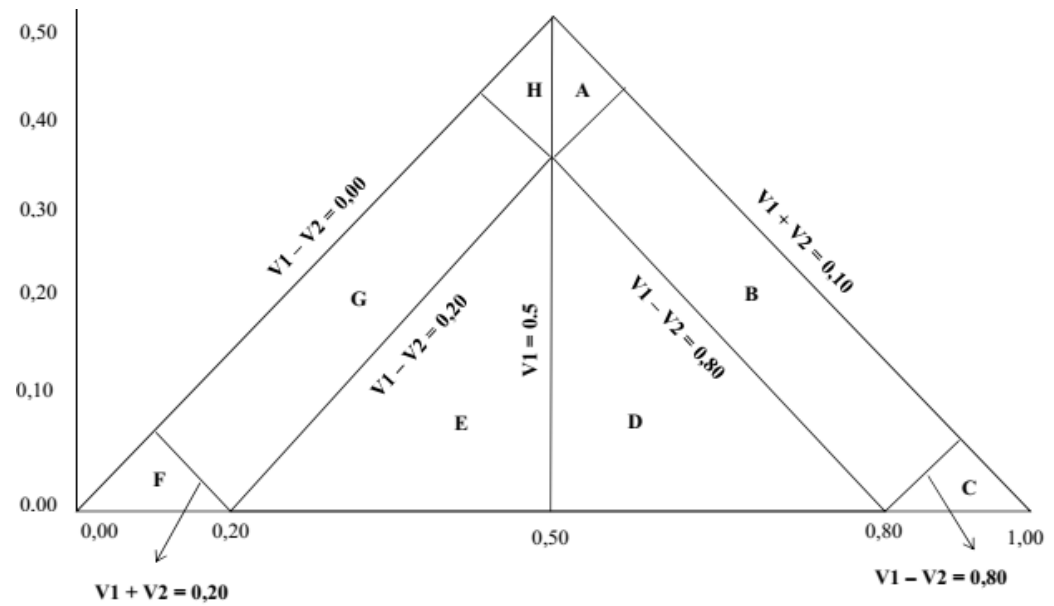

Source: Author

\footnotetext{
${ }^{8}$ For more on the ecological inference problem when assuming individual strategic behaviour based on aggregated data, see Karp et al. (2002), Karp (2009).

${ }^{9}$ The segmented Nagayama diagrams were created using the ElectMach election software. (Chytilek - Kutner 2005)

${ }^{10}$ These sub-divisions are delimited by the two sloping triangles and by a vertical line at $\mathrm{V} 1=0.5$. At the horizontal axis of the diagram (Figure 1), we see the vote share of the largest party (candidate), V1 (from 0 to $100 \%$ ), and at the vertical axis, the vote share of the second largest party (candidate), V2 (from 0 to $50 \%$ ). The triangle is delimited by the horizontal axis and the two lines, $\mathrm{V} 1-\mathrm{V} 2=0.00$ and $\mathrm{V} 1+\mathrm{V} 2=1.00$. They intersect where V2 equals 50 , the logical maximum for the second largest party (candidate) under any pattern of competition. (cf. Grofman et al. 2004: 275-279)
} 


\section{Strategic voting in the 2013 and 2017 elections of Slovakian regional presidents}

\section{Size of precinct-level competition}

Table 1 presents the ENEP in the Slovakian precincts, showing that electoral competition in elections of regional presidents in 2017 is very far from twoparty competition and a Duvergerian logic. At the national level, almost threequarters $(74.50 \%)$ of all Slovakian precincts had an ENEP greater than 2.5, violating Duverger's law. More importantly, only $8.31 \%$ of the precincts had an ENEP lower than 2.0, and at the same time, the typical ENEP value in all precincts exceeded three (3.27), with a maximum of 8.04. Similarly, we found a high concentration of precincts above the level of 2.5 in most of the Slovakian regions, with one exception - the Trnava region.

The most striking outlier to Duverger's assumptions is the Bratislava region. Here, 566 out of $569(99.47 \%)$ precincts had an ENEP greater than 2.5, with a mean value of 5.71. In other regions, the mean values of ENEP were much lower (between 2.75 and 3.53), but electoral competition in a vast majority of precincts remained far away from the Duvergerian equilibrium. In two regions (Trenčín and Košice), the percentage of such precincts approached or exceeded two-thirds and in four other remaining regions, it exceeded three-quarters (Prešov) or even four-fifths (Banská Bystrica, Žilina, Nitra). Only the results from Trnava, as one of the eight Slovakian regions, thus show values of ENEP which in most cases confirmed the Duvergerian assumption of two-party competition.

Figure 2 outlines the effective number of competing candidates in all of Slovakia and across the Slovak regions, confirming the finding presented above. Especially in Bratislava, we see only 10 precincts $(1,76 \%)$ under the level of three effective candidates, while most precincts have between five and six $(231$, or $40.6 \%)$ or between six and seven $(229$, or $40.25 \%)$ effective candidates, which reflected Cox's non-Duvergerian equilibrium and can be interpreted as an indicator of voters' limited rationality or problems with strategic decisions. Very contrasting results were found in the neighbouring Trnava region. Here, $82.06 \%$ of the precincts (430 out of 524) had an ENEP lower than 2.5, and out of them almost one-third (29.01\%) lower than 2.0 (with a mean value of 2.25), showing almost full compliance of voter behaviour with the Duvergerian logic.

The remaining six regions were located somewhere between these two "extremes", although all were closer to the Bratislava region - none of them had over half of the precincts approaching the value indicating two-party competition. In the best case, the share of precincts which had an ENEP lower than 2.5 was about one-third (34.78 \% in Košice, or $31.89 \%$ in the Trenčín 
Table 1: Distribution of $\boldsymbol{E N E P}$ - 2017 election of regional presidents

\begin{tabular}{|c|c|c|c|c|c|c|}
\hline Region & $\underset{(\min )}{\boldsymbol{E N E P}}$ & $\begin{array}{c}\boldsymbol{E N E P} \\
(\max )\end{array}$ & $\underset{(\text { mean })}{E N E P_{\text {micro }}}$ & $\begin{array}{c}E N E P \\
<2.0 \\
(\% / n)\end{array}$ & $\begin{array}{c}E N E P= \\
2.01-2.50 \\
(\% / n)\end{array}$ & $\begin{array}{l}\text { ENEP } \\
>2.51 \\
(\% / n) \\
\end{array}$ \\
\hline Bratislava & 2.01 & 8.04 & 5.71 & 0 & $0.53(3)$ & $99.47(566)$ \\
\hline Trnava & 1.31 & 4.16 & 2.25 & $29.01(152)$ & 53.05 (278) & $17.94(94)$ \\
\hline Trenčín & 1.18 & 4.94 & 2.76 & $11.76(76)$ & $20.12(130)$ & $68.11(440)$ \\
\hline Nitra & 1.10 & 6.72 & 3.53 & $6.02(45)$ & $7.76(58)$ & $86.21(644)$ \\
\hline Žilina & 1.30 & 5.23 & 3.06 & $2.56(18)$ & $12.64(89)$ & $84.80(597)$ \\
\hline $\begin{array}{l}\text { Banská } \\
\text { Bystrica }\end{array}$ & 1.17 & 6.96 & 3.20 & $2.51(23)$ & $15.30(140)$ & $82.19(752)$ \\
\hline Prešov & 1.00 & 7.01 & 3.20 & $8.52(86)$ & 12.59 (127) & 78.89 (796) \\
\hline Košice & 1.15 & 7.09 & 2.75 & $11.24(96)$ & $23.54(201)$ & $65.22(557)$ \\
\hline Slovakia total & 1.00 & 8.04 & 3.27 & 8.31 (496) & 17.21 (1026) & $74.50(4446)$ \\
\hline
\end{tabular}

Source: Statistical Office of the Slovak Republic, author's own calculations.

Note: $E N E P_{\text {micro (min) }}-$ minimum value of $E N E P$ at precinct level, $E N E P_{\text {micro (max) }}-$ maximum value of $E N E P$ at precinct level, $E N E P_{\text {micro (mean) }}$ - average value of $E N E P$ in the aggregate of precincts. $\mathrm{N}=5968$ (Slovakia), 569 (Bratislava), 524 (Trnava), 646 (Trenčín), 747 (Nitra), 704 (Žilina), 915 (Banská Bystrica), 1009 (Prešov), 854 (Košice).

region), while this number fell to one-fifth or below in the remaining regions. However, even among these regions there were striking differences in the extent of voters' strategic behaviour. While Trenčín, Košice or Žilina had also limited numbers of precincts with more than four $(1.39 \%$ in Trenčín, $4.10 \%$ in Košice, or $5.54 \%$ in the Žilina region) or five effective candidates $(0.7 \%$ in Košice, or $0.28 \%$ in the Žilina region), three other regions show much more precincts with high numbers of effective candidates. The number of precincts with the ENEP greater than 4 reached $12.9 \%$ (Banská Bystrica), $16.15 \%$ (Prešov), or $32.0 \%$ (Nitra), with the number of precincts with the ENEP greater than 5 reaching between $2.38 \%$ (Prešov) and $3.48 \%$ (Nitra).

Figure 2: Distribution of $E N E P$ - 2017 election of regional presidents

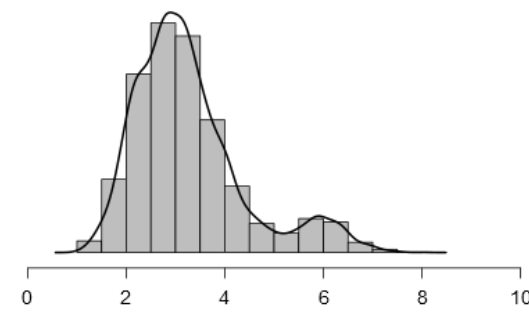

Slovakia

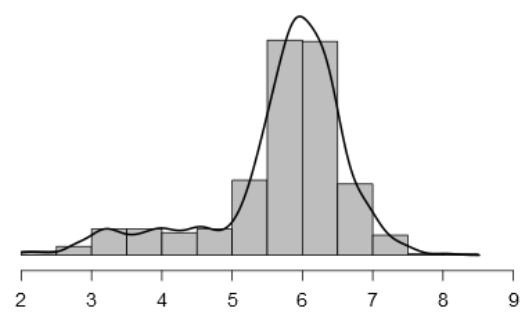

Bratislava region 


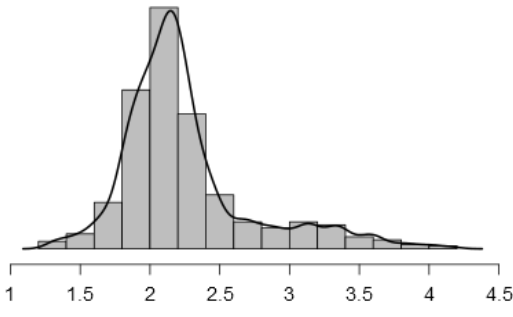

Trnava region

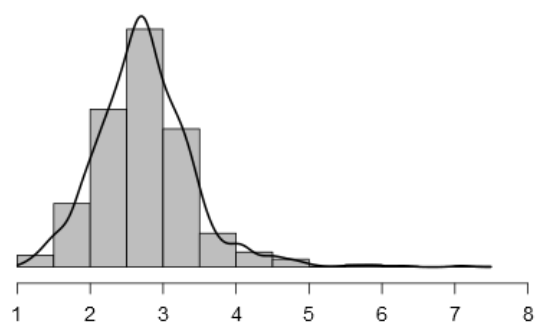

Košice region

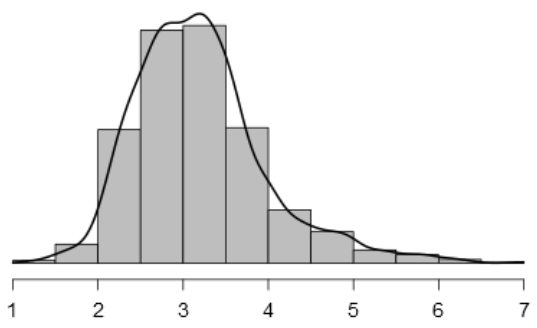

Banská Bystrica region

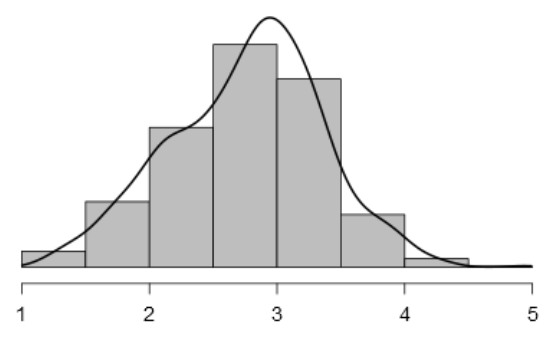

Trenčín region

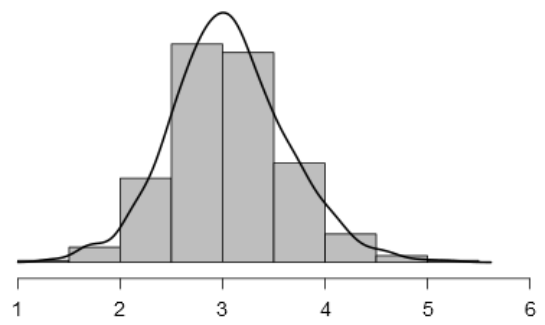

Žilina region

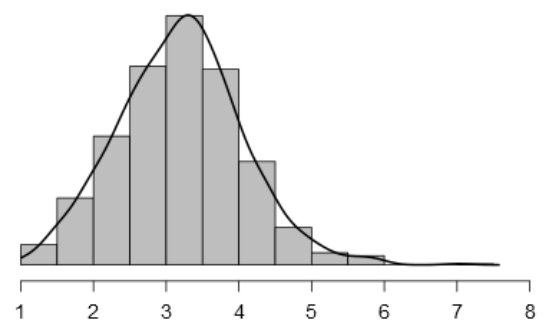

Prešov region

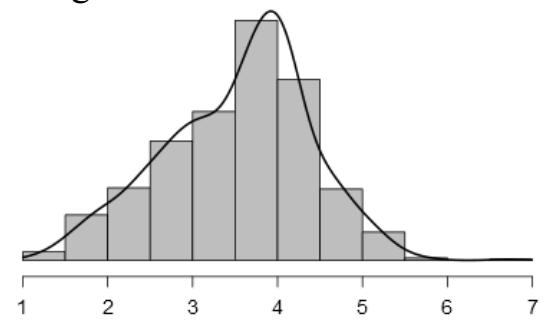

Nitra region

Source: Statistical Office of the Slovak Republic, author's own calculations.

When we compare results of the 2017 regional elections with the previous elections in 2013 (Table 2), we can see, in contrast to Duverger's assumptions, 
that the introduction of FPTP, instead of TRS, did not result in an increase of two-party competition and strategic voting. Whereas the mean value of ENEP at precinct level (for all Slovakian precincts) reached 2.63 in the last elections of regional presidents held under the TRS in 2013, the first use of the FPTP in 2017 was accompanied by an increase to $3.27^{11}$. Similarly, there were only $53.84 \%$ of the precincts with ENEP greater than 2.5 in 2013, indicating violation of the Duverger's law, whereas number of such precincts increased to $74.50 \%$ in 2017, and, in contrast to theoretical expectations, competition at precinct level went far away from the Duvergerian equilibrium.

The same was true for all regions except Trnava, the only region where the introduction of FPTP in 2017 lead to increasing two-party competition and decreasing number of precincts with ENEP lower than 2.5 (from $33.97 \%$ to $17.94 \%)$. In six other regions, the number of precincts with an ENEP greater than 2.5 (in violation of Duverger's law) rose at rates between 10.28 (Trenčín) and 60.10 percentage points (Nitra), i.e. 28.08 p.p. on average; in Košice, the character of electoral competition remained almost the same.

Table 2: Distribution of $E N E P$ - 2013 election of regional presidents

\begin{tabular}{|c|c|c|c|c|c|c|}
\hline Region & $\underset{(\mathrm{min})}{E N E P_{\text {micro }}}$ & $\begin{array}{c}\boldsymbol{E N E P _ { \text { micro } }} \\
(\max )\end{array}$ & $\underset{\text { (mean) }}{E N E P_{\text {micro }}}$ & $\begin{array}{c}E N E P \\
<2.0 \\
(\% / n) \\
\end{array}$ & $\begin{array}{c}E N E P= \\
2.01-2.50 \\
(\% / n)\end{array}$ & $\begin{array}{l}\text { ENEP } \\
>2.51 \\
(\% / \mathrm{n}) \\
\end{array}$ \\
\hline Bratislava & 1.34 & 6.81 & 3.13 & $1.26(7)$ & $9.57(53)$ & 89.17 (494) \\
\hline Trnava & 1.46 & 4.51 & 2.38 & $21.56(113)$ & 44.47 (233) & 33.97 (178) \\
\hline Trenčín & 1.14 & 5.47 & 2.73 & $19.22(124)$ & $22.95(148)$ & $57.83(373)$ \\
\hline Nitra & 1.00 & 4.46 & 2.08 & $48.18(358)$ & $25.71(191)$ & 26.11 (194) \\
\hline Žilina & 1.07 & 3.73 & 2.35 & $28.00(196)$ & 29.14 (204) & $42.86(300)$ \\
\hline $\begin{array}{l}\text { Banská } \\
\text { Bystrica }\end{array}$ & 1.00 & 6.50 & 2.95 & $11.62(106)$ & $18.20(166)$ & $70.18(640)$ \\
\hline Prešov & 1.00 & 5.56 & 2.37 & $30.01(301)$ & $24.93(250)$ & $45.06(452)$ \\
\hline Košice & 1.08 & 6.08 & 3.03 & $15.86(135)$ & $16.45(140)$ & $67.69(576)$ \\
\hline Slovakia total & 1.00 & 6.81 & 2.63 & $22.56(1338)$ & 23.42 (1389) & $54.03(3194)$ \\
\hline
\end{tabular}

Source: Statistical Office of the Slovak Republic, author's own calculations.

Note: $E N E P_{\text {micro (min) }}-$ minimum value of $E N E P$ at precinct level, $E N E P_{\text {micro (max) }}$ - maximum value of $E N E P$ at precinct level, $E N E P_{\text {micro (mean) }}-$ average value of $E N E P$ in the aggregate of precincts. $N=5932$ (Slovakia), 554 (Bratislava), 524 (Trnava), 645 (Trenčín), 743 (Nitra), 700 (Žilina), 912 (Banská Bystrica), 1003 (Prešov), 851 (Košice).

\footnotetext{
11 In the case of the TRS, the $S F$-ratio is calculated as the vote share secured by the third loser in relation to the votes secured by the second loser in the first round of elections. (Cox 1997)
} 


\section{Distribution of SF-ratios across the precincts}

Generally, the distribution of $S F$-ratios in the whole Slovakia in 2017 shows that only slightly more than a fifth $(21.01 \%)$ of the precincts had competition indicating a Duvergerian equilibrium (the $S F$ values less than 0.25). On the other hand, as only slightly above a quarter $(26.01 \%)$ of the precincts had values of the $S F$-ratio above the upper limit, and electoral competition in most precincts $(52.98 \%)$ ranges somewhere between the lower and upper thresholds, a more detailed view at the regional level is needed to show the shape of the electoral competition across Slovakia. As with the values of effective number of parties (candidates), even the values of $S F$-ratios (Table 3 and Figure 3) confirmed, with the exceptions of the Trnava, Košice and to some minor extent the Žilina and Prešov regions, the prevalence of multi-party electoral competition and voters' limited willingness/ability to vote strategically by abandoning hopeless candidates.

Table 3: Distribution of $S F$-ratios - 2017 election of regional presidents

\begin{tabular}{|c|c|c|c|c|}
\hline Region & $S F<0.250(\% / \mathbf{n})$ & $S F=0.251-0.749(\% / n)$ & $S F>0.750(\% / n)$ & Total (n) \\
\hline Bratislava & $0.00(0)$ & $31.81(181)$ & $68.19(388)$ & $100.0(569)$ \\
\hline Trnava & $68.13(357)$ & $24.62(129)$ & $7.25(38)$ & $100.0(524)$ \\
\hline Trenčín & $4.18(27)$ & $64.71(418)$ & $31.11(201)$ & $100.0(646)$ \\
\hline Nitra & $4.95(37)$ & $49.40(369)$ & $45.65(341)$ & $100.0(747)$ \\
\hline Žilina & $19.18(135)$ & $66.05(465)$ & $14.77(104)$ & $100.0(704)$ \\
\hline Banská Bystrica & $8.96(82)$ & $67.98(622)$ & $23.06(211)$ & $100.0(915)$ \\
\hline Prešov & $18.33(185)$ & $65.31(659)$ & $16.35(165)$ & $100.0(1009)$ \\
\hline Košice & $50.59(432)$ & $42.97(367)$ & $6.44(55)$ & $100.0(854)$ \\
\hline Slovakia total & $21.01(1254)$ & $52.98(3162)$ & $26.01(1552)$ & $100.0(5968)$ \\
\hline
\end{tabular}

Source: Statistical Office of the Slovak Republic, author's own calculations.

As a result, only the Trnava and Košice regions had most precincts (68.13\%, or $50.59 \%$ respectively) indicating a Duvergerian equilibrium, with a limited number of precincts where the $S F$-ratio values were above the upper limit ( $7.25 \%$, or $6.44 \%$ respectively). Especially the distribution of $S F$-ratios in the Trnava region was almost perfectly consistent with two-party competition, as $41.22 \%$ of the precincts had $S F$-ratio values smaller than or equal to 0.1 . In the Košice region, this category included only $3.86 \%$ of the precincts and most of the values of the $S F$-ratio ranged between $0.1-0.2$ $(33.02 \%)$ or $0.2-0.3(23.54 \%)$. 
In contrast, in the Žilina and Prešov regions, we found results indicating a Duvergerian equilibrium only in less than a fifth of the precincts $(19.18 \%$, or $18.33 \%$ respectively), although the proportion of precincts with competition indicating a non-Duvergerian equilibrium was not considerably higher than in the Trnava and Košice regions: $14.77 \%$ in Žilina and $16.35 \%$ in Prešov. Moreover, almost one-third of the $S F$-ratio values in the Žilina region concentrated around the level of $0.25-0.40(31.41 \%),{ }^{12}$ nearing the level which indicates Duvergerian equilibrium, while the Prešov region's $S F$-ratio values were more evenly distributed among the various categories, even if they moved far away from the lower limit; this can be demonstrated by the share of the most frequent category around the level of $0.40-0.45$, which included only $8.82 \%$ of the precincts.

Finally, three remaining regions represent cases where the election results indicated voters' limited willingness and limited ability to vote strategically by abandoning hopeless candidates in favour of those with a chance to succeed, i.e. similar voter behaviour as we found in the Bratislava region. In Banská Bystrica, the pattern of strategic failure, with many voters casting their ballot for candidates that ended up polling third, fourth, or lower, was similar to the Prešov region, although with only half of the precincts $(8.96 \%)$ indicating a Duvergerian equilibrium and on the contrary, almost double the number of precincts $(23.06 \%)$ with high $S F$ values indicating non-Duvergerian equilibria.

In contrast, electoral competition in the Trenčín and Nitra regions was most distant from the Duvergerian logic and signalized a departure from Duverger's law, although even electoral competition in these two regions was far from uniform. Both regions resemble each other only in the minimum number of precincts which correspond to the criteria of two-party competition, as values of $S F$-ratio under the lower threshold affected less than $5 \%$ of precincts (4.18\% in Trenčín, or $4.95 \%$ in the Nitra region respectively), whereas they significantly differ in other categories. As stated above, electoral competition in the Trenčín region was characterised by almost absent two-party competition, and similarly a very small number of districts nearing two-party competition ( $S F$ values around the level of $0.2-0.3$ ). On the other hand, the distribution of $S F$ values in the remaining categories was fairly balanced (although with $31.11 \%$ of $S F$-ratio values crossing the upper limit), which is in sharp contrast to voter behaviour in the neighbouring Nitra region. Here we can see, similarly as in the Bratislava region, an almost linear pattern, although one that is almost totally at odds with Duverger's assumptions. We found only $0.80 \%$ of the precincts concentrated around the level of $0.0-0.1$, followed by an increase, whereas a very large number of the precincts $(19.54 \%)$ had $S F$-ratio values

12 Specifically, $11.10 \%$ of the precincts between the values of $0.25-0.3$ and $20.31 \%$ in the $0.3-0.4$ interval. 
higher than 0.9 (with $45.65 \%$ of the precincts exceeding the upper limit). This indicates very high levels of strategic coordination failure, with many voters casting their ballot for candidates other than the two strongest contenders who had a real chance to succeed.

Figure 3: Distribution of $S F$-ratios - 2017 election of regional presidents
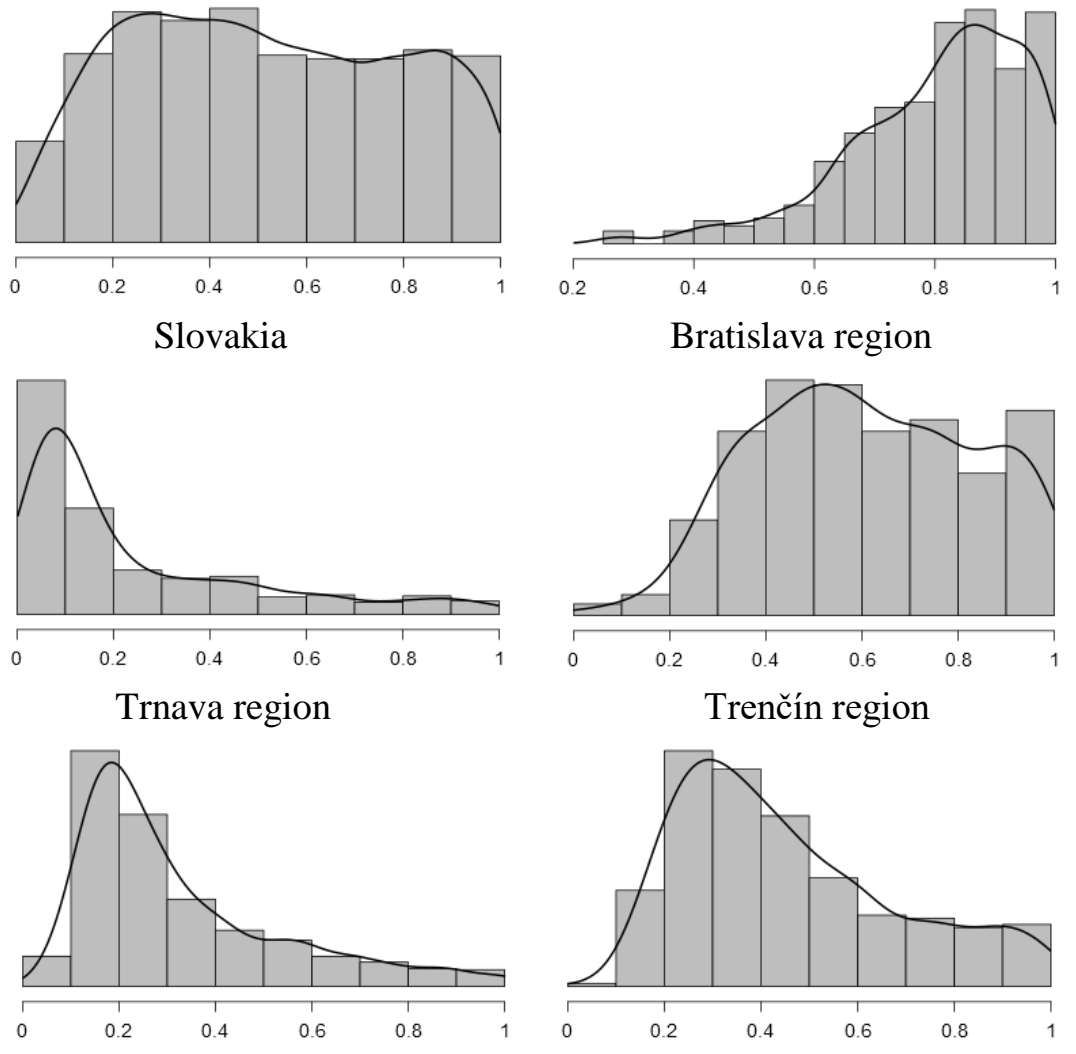

Košice region

Žilina region

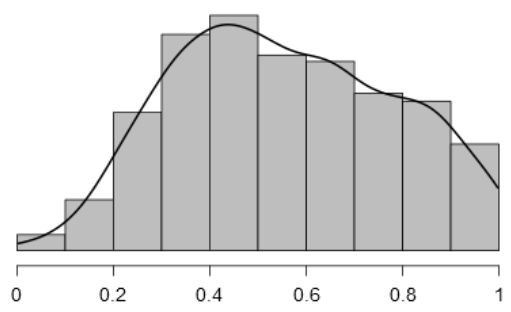

Banská Bystrica region

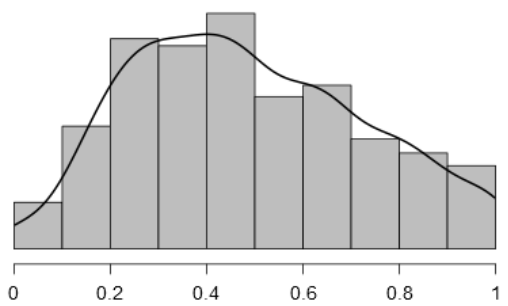

Prešov region 


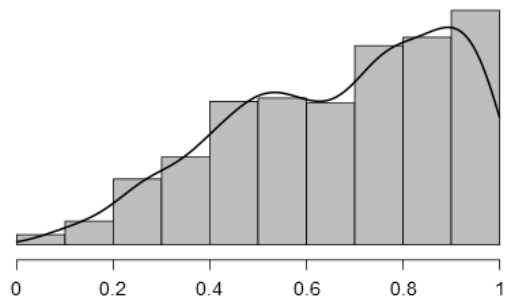

Nitra region

Source: Statistical Office of the Slovak Republic, author's own calculations.

Comparison of the ENEP values between the elections of regional presidents in 2013 and 2017 showed rather a departure from the two-party electoral contest under the new FPTP system. However, the distribution of $S F$ ratios across the precincts suggests a partly different picture. First, we found almost the same proportion of $S F$-ratio values in all three categories, with only $22.37 \%$ of precincts indicating Duvergerian equilibrium. On the other hand, interregional variation of $S F$-ratios between the elections was much higher than in the case of $E N E P$ values. In many cases, we can see shifts of regions whose 2013 election results were in conformity with Duverger's expectations to the category indicating a non-Duvergerian equilibrium and vice versa.

Table 4: Distribution of $\boldsymbol{S} \boldsymbol{F}$-ratios - 2013 election of regional presidents

\begin{tabular}{|c|c|c|c|c|}
\hline Region & $S F<0.250(\% / \mathbf{n})$ & $S F=0.251-0.749(\% / n)$ & $S F>0.750(\% / n)$ & Total (n) \\
\hline Bratislava & $16.43(91)$ & $75.27(417)$ & $8.30(4.60)$ & $100.0(554)$ \\
\hline Trnava & $26.15(137)$ & $54.39(285)$ & $19.47(102)$ & $100.0(524)$ \\
\hline Trenčín & $7.60(49)$ & $61.09(394)$ & $31.32(202)$ & $100.0(645)$ \\
\hline Nitra & $39.43(293)$ & $45.22(336)$ & $15.34(114)$ & $100.0(743)$ \\
\hline Žilina & $55.86(391)$ & $38.71(271)$ & $5.43(38)$ & $100.0(700)$ \\
\hline Banská Bystrica & $19.96(182)$ & $58.99(538)$ & $21.05(192)$ & $100.0(912)$ \\
\hline Prešov & $10.27(103)$ & $46.26(464)$ & $43.47(463)$ & $100.0(1003)$ \\
\hline Košice & $4.00(34)$ & $50.65(431)$ & $45.36(386)$ & $100.0(851)$ \\
\hline Slovakia total & $22.37(1327)$ & $51.64(3063)$ & $25.99(1542)$ & $100.0(5932)$ \\
\hline
\end{tabular}

Source: Statistical Office of the Slovak Republic, author's own calculations.

\section{Nagayama diagrams for precinct-level competition}

The high concentration of precincts around the level of three effective candidates in most Slovakian regions, or even six in the case of Bratislava, as well as only a limited number of $S F$ values indicating Duvergerian equilibrium 
in 2017, respectively, bring the question about the nature of competitiveness at precinct level to the fore. The results of segmented Nagayama diagrams for the elections of 2017 are presented in Figure 4. The values of ENEP and SF-ratios (presented above) showed that the character of the elections of regional presidents was not entirely uniform across all regions, often far from the Duvergerian logic; neither the results of Nagayama diagrams offer a different (more homogenous) picture. Generally, we found five different patterns of electoral competition.

The first of the patterns is characteristic of the Bratislava region only, and confirms divergence from Duverger's assumptions of two-party competition. The most of Bratislava's precincts lie in segment B (two-party dominance combined with 'non-competitiveness', as the largest contender obtained more than $50 \%$ of the vote and was much stronger than the second strongest candidate in the precinct), and segment $\mathrm{D}$ (neither strong or complete single- or two-party dominance nor political competitiveness), although most of the precincts approached the common border between these two segments. In contrast, we found only a very limited number of districts in the segments with no substantial third-party strength: segment $\mathrm{H}$ (competitive dominance of the top two parties where none of the top two parties was able to gain more than $50 \%$ of the vote in the district), and especially in segment A (competitive dominance of the top two parties where the winner takes $50 \%$ or more of the total vote in the district), but also in segment $G$ (competitive multi-party electoral competition).

The second pattern, radically different from the previous one, was found in the Trnava region. Here the most precincts lie in the B, A and $\mathrm{H}$ segments, indicating two-party dominance, with an absolute majority of precincts in segment B which is characterized by 'non-competitiveness' (as the largest contender obtained more than $50 \%$ of the vote) and substantially limited minor party strength, as signalized by the large number of precincts located close to or on the line between the vertices connecting the main vertex and the right vertex of the triangle, i.e. the area (or line, respectively) where two parties (candidates) gain entirely all votes. In contrast, there were almost no precincts with neither political competitiveness nor strong/complete single- or two-party dominance (segments $\mathrm{D}, \mathrm{E}$ ) and also a limited number of precincts in segment $\mathrm{G}$ indicating competition between more than two parties (i.e. the competitive multi-party segment of the diagram), although most of the districts in this segment approached segment $\mathrm{H}$, which indicates strong competitive two-party dominance, too.

Another case (third pattern) of the precincts with prevalence (although much weaker) of two-party competition is represented by Trenčín and much more by the Košice region. In both cases, we found a less than uniform character of the 
electoral competition, characterized by a strong mix of non-competitive twoparty configurations with a significant number of multiparty configurations. Most of the precincts (although not an absolute majority) lie in the B segment; however, in contrast to the Trnava region, we found also a very high presence of precincts with substantial third-party strength and multi-party competition (segment G), reaching one-fourth in Košice or almost one-third in the Trenčín region, respectively, combined with only few precincts in segments $\mathrm{A}$ and $\mathrm{H}$ which contain areas with strong (competitive) two-party dominance; the Košice region was a minor exception with slightly more precincts in segment $\mathrm{H}$, i.e. electoral competition characterized by strong competitive two-party dominance yet without absolute dominance of one of the top two parties (candidates).

In contrast to the previous cases, the fourth pattern was identifiable in three regions with a relatively high degree of uniformity among them. The results for the Banská Bystrica, Žilina and Prešov regions show that almost half of the precincts had multi-party configurations (segment $\mathrm{G}$ ), thus distorting the Duvergerian logic, although most of them approached segment $\mathrm{H}$ representing two-party competition. Most of the remaining precincts then witnessed twoparty competition with limited minor party strength (segments $\mathrm{B}, \mathrm{H}$ and $\mathrm{A}$ segments), with prevalence of non-competitive two-party dominance (segment B) in the Prešov region accompanied by higher presence in segment $\mathrm{H}$ (competitive dominance of the top two candidates). Moreover, at least a tenth of the precincts (in each region) showed neither strong or complete single- or two-party dominance nor political competitiveness (segments D and E).

Finally, Nitra (the fifth pattern) was the second of all Slovakian regions where we found prevalence of multi-party competition, although with quite a different pattern than in the Bratislava region. More importantly, the Nitra region was only one of the regions where an absolute majority of precincts showed multi-party competition (although nearing segment $\mathrm{H}$ as in the previous cases). Thus, compared to the Bratislava region, Nitra exhibits only half the number of precincts (about one-fifth) in segment B (non-competitive two-party competition), which was most characteristic of Bratislava's electoral contest, and an even more limited occurrence of strong two-party (competitive) dominance (A and $\mathrm{H}$ segments). 
Figure 4: Segmented Nagayama diagrams - 2017 election of regional presidents

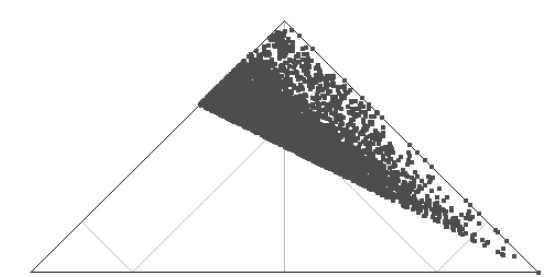

Slovakia

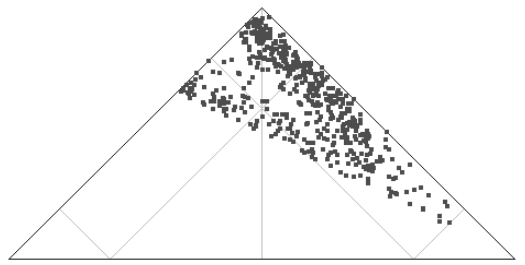

Trnava region

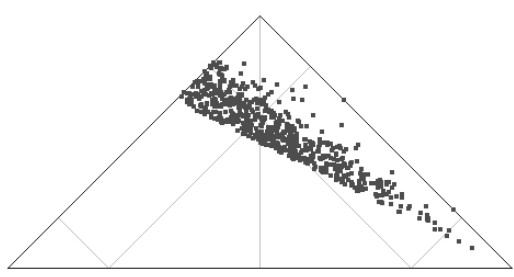

Košice region

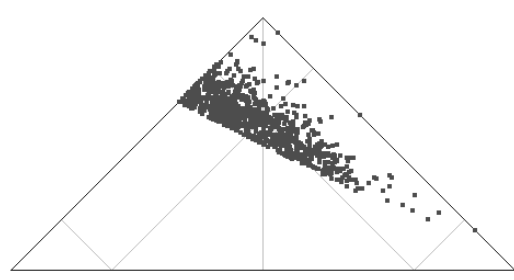

Banská Bystrica region

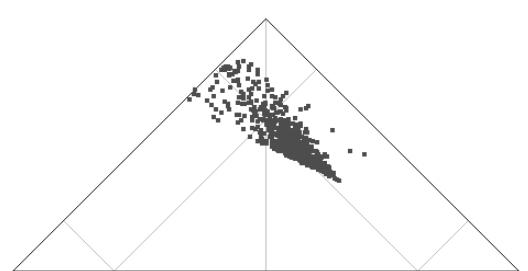

Bratislava region

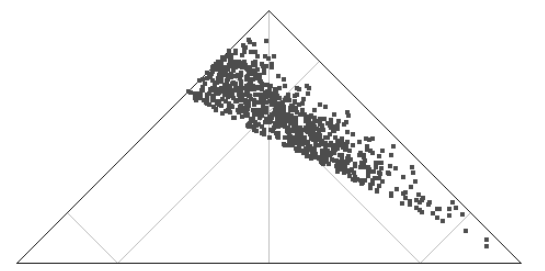

Trenčín region
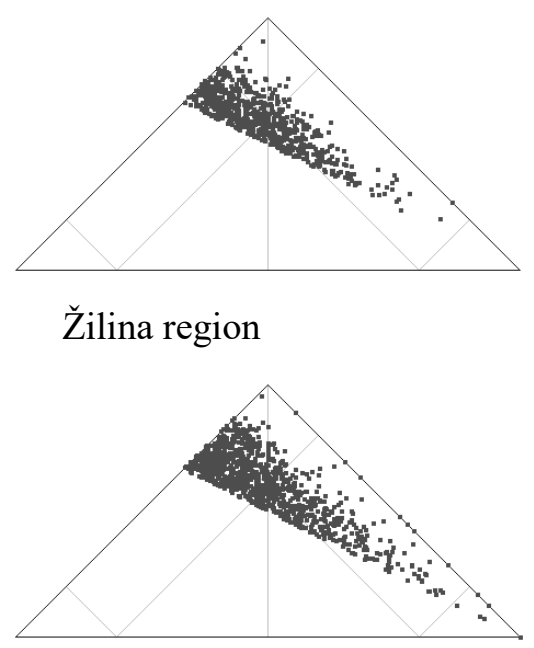

Prešov region 


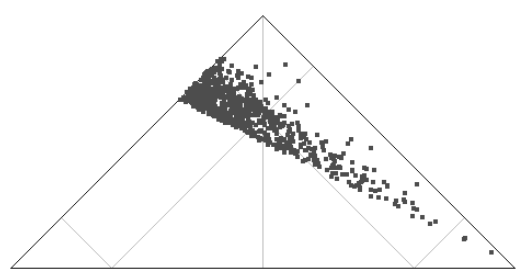

Nitra region

Source: Statistical Office of the Slovak Republic, author's own calculations.

Furthermore, and more importantly, comparison of Nagayama diagrams between the elections of 2013 and 2017 shows that some regions saw relatively significant transformation of the nature of competitiveness, a fact already confirmed at the level of all Slovakian precincts. In 2013, most of the precincts (almost half) lay in segment B (two-party dominance combined with 'noncompetitiveness', as the largest contender obtained more than $50 \%$ of the vote and was much stronger than the second strongest candidate in the precinct), followed by segment $\mathrm{G}$ (competitive multi-party electoral competition). In contrast, in 2017, both categories were almost equal (with about one-third of precincts), indicating a general increase of multipartism. However, in both elections, most precincts in segment $\mathrm{G}$ were found near segment $\mathrm{H}$ (strong competitive two-party dominance).

As for individual regions, Trenčín and Trnava were the only regions where the character of electoral contest remained almost the same, with only a mild shift of precincts from segment $\mathrm{H}$ to A in Trnava. Košice was, together with Trnava and Trenčín, one of the regions where two-party competition not only prevailed, but strengthened due to continuing prevalence of the form of competition in segment B (non-competitive two-party dominance); at the same time, a large part of precincts moved from segment $\mathrm{G}$ to segment $\mathrm{H}$, leaving only approximately one-fourth of precincts in competitive multi-party segments.

On the opposite side, there were the Nitra, Prešov and Žilina regions, where we found the strongest signs of a shift to multi-party competition. In 2017, segment $\mathrm{G}$ brought together almost half of the precincts (more than half in the case of Nitra), whereas segment B (two-party dominance combined with 'noncompetitiveness') was predominant in 2013 (with half of all precincts or even more than two-thirds in the case of the Nitra region); however, even in 2017, most precincts in segment $\mathrm{G}$ approached segment $\mathrm{H}$ (strong competitive twoparty dominance without absolute dominance of one of the top two parties). The Banská Bystrica region did not undergo such a strong transformation: already in 2013, it was characterized by a strong mix of non-competitive two- 
party configurations (segment B) with a significant number of multiparty configurations (segment $\mathrm{G}$ ), each exceeding one-third of the precincts.

Finally, although the electoral competition in Bratislava was in many aspects far from Duverger's theoretical assumptions in 2017 (especially having one-third of precincts with neither strong or complete single- or two-party dominance nor political competitiveness - overwhelmingly in segment D), there was a significant increase in two-party contest from 2013. Specifically, the number of precincts in segments $\mathrm{B}, \mathrm{H}$, and A roughly doubled and, at the same time, segment $\mathrm{G}$ (multi-party competition) went from almost half of all precincts to near zero.

Figure 5: Segmented Nagayama diagrams - 2013 election of regional presidents

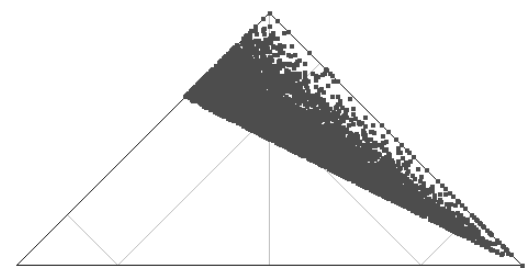

Slovakia

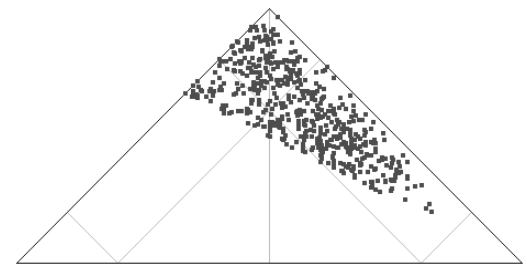

Trnava region

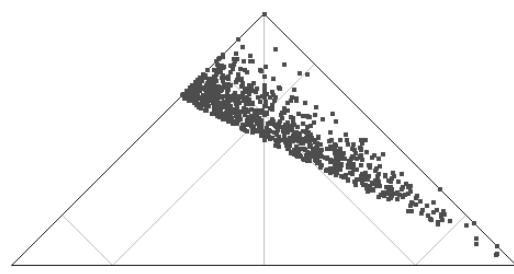

Košice region

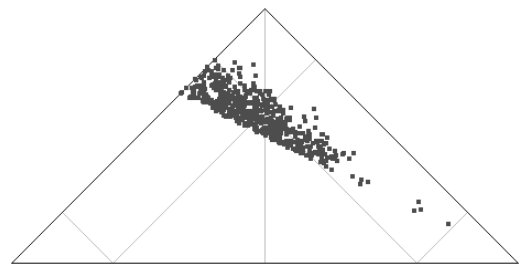

Bratislava region

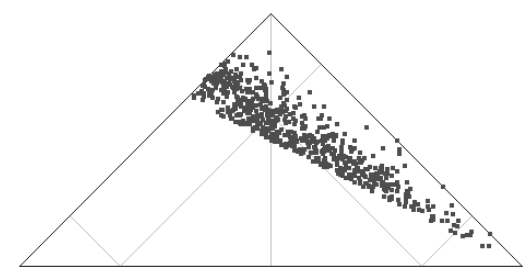

Trenčín region

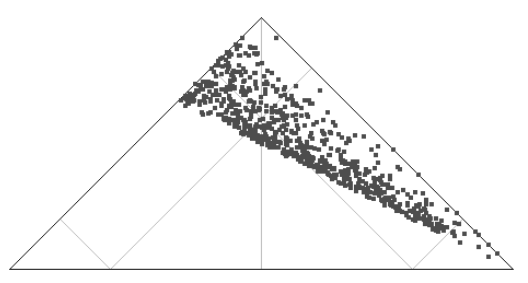

Žilina region 


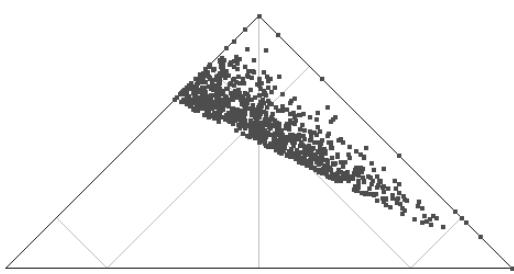

Banská Bystrica region

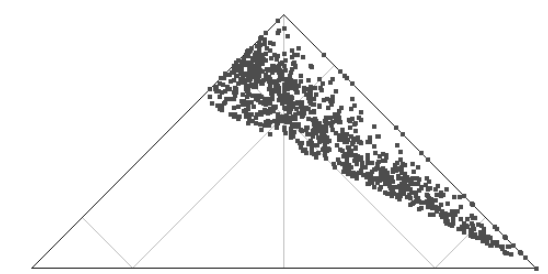

Prešov region

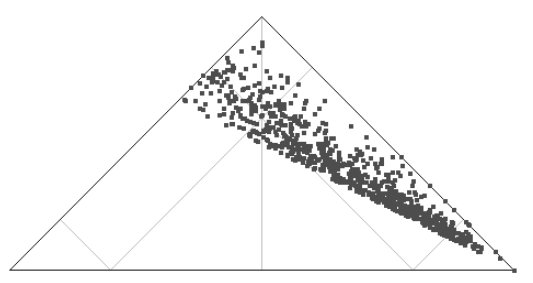

Nitra region

Source: Statistical Office of the Slovak Republic, author's own calculations.

\section{Concluding remarks and discussion}

The main aim of the article has been to analyse the character of Slovak regional electoral competition (more precisely election of presidents of self-governing regions) in the context of Slovakia's new electoral law, which was first used in 2017, in comparison with the results of the previous elections in 2013. We have especially addressed the question whether the electoral competition at precinct level was consistent with Duverger's law (two-party competition).

We used three alternative methods to study the assumptions related to Duverger's law, and came to several conclusions. First, our analysis showed that the effects of FPTP were not universal in the regional elections of 2017, as indicated by violation of Duverger's law in many precincts. For instance, the $E N E P$ values indicated that only a limited part of the precincts concentrated around the level of two and, contrarily, most of the precincts had ENEP values greater than 2.5, violating Duverger's law. De facto only the Trnava region, as one of eight regions, exhibited the prevalence of an electoral contest corresponding to Duverger's expectations, and almost the same was true for values of the $S F$-ratio as indicators of strategic voting (or failure), although in this case we found the prevalence of strategic voting also in the Košice region, similarly as in the Trnava region.

On the other hand, segmented Nagayama diagrams, as indicators of the nature (degree) of competitiveness, showed more promising outcomes regarding Duverger's theory and proved as perhaps the most suitable indicator 
of competitiveness and strategic behaviour (together with the values of ENEP). They addressed some of the shortcomings of the $S F$-ratio mentioned above and were clearly instrumental in identifying the patterns, and especially changes to patterns, of electoral competitiveness between elections. With regard to the elections of regional presidents in 2017, there were only three regions in Slovakia where we could confirm the prevalence of two-party competition (especially in Trnava), and even in these regions, the two-party contest was supplemented with a relative high presence of precincts which witnessed multiparty competition. On the other hand, most of the precincts with relatively substantial third-party strength neared areas which are already defined by strong competitive two-party dominance. This conclusion is true not only for the above-mentioned regions with only limited third-party strength (Trnava, Trenčín, Košice) but also for regions with a near-majority of precincts characterized by multi-party electoral competition, although with a not negligible number of precincts with two-party contest (Žilina, Prešov, Banská Bystrica), or the Nitra region where the number of precincts with multi-party electoral contests reached absolute majority. The same is also true for the Bratislava region, as it had more precincts in segments characterised by neither strong or complete single- or two-party dominance nor political competitiveness (instead of segments with multi-party competition) which, however, mostly approached the segment with two-party competition, albeit in the noncompetitive area of diagram, in contrast to all other regions.

Nevertheless, the main advantage of Nagayama diagrams emerges in comparing the election results of 2013 a 2017, which demonstrates a shift from two-party dominance to competitive multipartism, although in most cases nearing to those segments of the diagram that indicate some form of two-party contest. However, an analysis of individual regions shows a somewhat different picture. On one hand, there were two regions, Trnava and Trenčín, that kept their bipartism almost unchanged, along with the Košice region where we found signs of strengthening two-party dominance. Bratislava saw not only a significant increase of precincts with two-party competition, but also of those with neither strong or complete single- or two-party dominance nor political competitiveness. On the other hand, there were the Nitra, Prešov and Žilina regions where we found the strongest signs of transformation to multi-party competition, although again with more precincts approaching segments with a strong position of two top-ranking candidates; a similar development was seen also in Banská Bystrica, although the closely watched region's initial situation in 2013 was different, characterized by a strong equal mix of non-competitive two-party configurations and multiparty configurations ${ }^{13}$.

13 In 2013, Marián Kotleba, chairman of the extreme-right populist Kotleba - People's Party Our Slovakia (LSNS), won the regional president's post in the second round of the contest. However, he lost to independent candidate Ján Luntner in 2017. 
Second, according to theoretical expectations, the introduction of FPTP, instead of TRS, should lead to an increase of two-party competition and strategic voting, but the opposite was true. For instance, whereas the mean value of ENEP at precinct level (for all Slovakian precincts) reached 2.63 in the last elections of regional presidents held under the TRS in 2013, the first use of the FPTP in 2017 was accompanied by an increase to 3.27. Similarly, there were only $53.84 \%$ of the precincts with ENEP greater than 2.5 in 2013, indicating violation of the Duverger's law, whereas number of such precincts increased to $74.50 \%$ in 2017. Generally, in contrast to theoretical expectations, competition at precinct level went far away from the Duvergerian equilibrium, as only one out of the eight regions, Trnava, saw increasing two-party competition after the introduction of FPTP in 2017.

Compared to number of effective candidates, the values of $S F$-ratio (again for all Slovakian precincts) remained almost unchanged between the elections of 2013 and 2017, as electoral contests indicating bipolar competition and Duvergerian equilibrium were found in one-fifth of the precincts (specifically in $22.37 \%$ in 2013 compared to $21.01 \%$ in 2017) and, similarly, $S F$-ratio values above the upper limit were almost equally in one-quarter of precincts (specifically in $25.99 \%$ in 2013 compared to $26.01 \%$ in 2017). Generally, these results showed that non-Duvergerian equilibrium, i.e. voters' limited rationality, or problems with strategic decisions, remained on almost the same level between the elections of 2013 and 2017. However, a closer look unveils that some regions with the same numbers of $S F$-ratios saw shifts to more strategic behaviour and others in the opposite direction.

Third, the above-mentioned violations to theoretical expectations lead to the question which factors can inhibit short-term instrumental rationality of voters, namely that voters will correctly analyse the situation and maximize their selfinterest, resulting in voting in accordance with the Duvergerian logic and expectations of Duverger's law. Here, the first interesting question is number of candidates in various regions, which could explain strategic failure of voters in regions with a too many candidates. However, when we briefly compare elections held under the TRS between 2001 and 2013 with the last elections in 2017, we see that the mean number of candidates in all regions, except Bratislava, saw a minor decrease or almost the same number of competing candidates. More importantly, while 17 candidates in the Bratislava region in the elections of 2017 can partly explain the limited ability to vote strategically by abandoning hopeless candidates in favour of those with a chance to succeed

Luntner received $48.53 \%$ of the vote, Kotleba $23.24 \%$ and $28.15 \%$ of the ballots were cast for third- or lower-ranking candidates $(3.47 \%$ even for ones that had given up their candidacy), suggesting that even Kotleba's re-election was not a dire enough prospect for a large part of voters to embrace strategic voting and support his strongest opponent. For more on the increasing success of the LSNS, see Gregor (2015), Mikuš, Gurňák and Máriássyová (2016), Maškarinec and Bláha (2016); Naxera and Krčál (2016); Durinová and Malová (2017). 
(whereas the mean number of candidates in Bratislava region was 11.8 during 2001 and 2013, it increased to 17 in 2017), the same conclusion cannot be applied to other regions, maybe with one other exception - the Trnava region, which has had the smallest number of candidates in a long-term perspective (7.0 during 2001 and 2013, or 5 in 2017 respectively).

For example, the number of candidates in the Nitra region is among the lowest in the long term (8.3 during 2001 and 2013, or 8 in 2017 respectively) and despite this fact the electoral competition in this region was farthest from two-party competition and Duverger's expectations in 2017; this was, however, quite opposed to 2013 when the electoral contest in Nitra (under the TRS) was to a large extent consistent with Duverger's expectations. In contrast, the Trenčín region, where the number of candidates was very similar as in the Nitra region (9.3 during 2001 and 2013, or 7 in 2017 respectively), was one of the regions where the electoral contest was much closer to two-party contest, as well as in the Košice region, where the number of candidates was, on the contrary, among the highest (10.5 during 2001 and 2013, or 11 in 2017 respectively), but this fact did not hinder voters in acting more strategically (in the 2017 as well as 2013 elections) than in the Nitra region, and the same was true even for the remaining regions.

Some further factors which can potentially hinder the effects of Duverger's law can be ascribed to electoral rules (as an institutional structure) in the Slovakian case. First, there is the possibility to run for election as an independent candidate together with very broad coalitions of parties in regional elections which often transcend the left-right division and thus undermine voters' ability to act strategically with a view to not wasting their votes. Second, the character of the elections of regional presidents, as second-order elections, must be mentioned. In the elections to the Slovakian parliament, voters rather prefer (or should prefer) strategic voting, or so-called 'voting with the head', as they may be afraid to waste their votes (although the proportional system is used). In contrast, in regional elections, voters may prefer 'sincere voting', or so-called 'voting with the heart', or abstention, as demonstrated by the very low turnout. This can be attributed to both the second-order character of the elections and to voters' problems with choice between broad coalitions, which often include many parties with not entirely coherent ideological profiles.

Furthermore, Spáč, Voda and Zagrapan (2016), who analysed the elections of members of Slovak regional parliaments, demonstrated an important role of alphabetical listing of candidates on the shared ballot list. The question is whether the same is of any relevance (especially among undecided voters) in the elections of regional presidents as they, too, use a single ballot listing all candidates alphabetically. 
The extent and influence of these factors, especially assumptions of secondorder elections theory, as well as the underlying mechanism, should be thoroughly investigated and as such, remain an important object for further research. Moreover, future research should provide a more comprehensive answer on whether (or to what extent) strategic behaviour of Slovak voters in elections of regional presidents can eventually strengthen in following elections. Indeed, some authors claim that the expectations of Duverger's law, as an equilibrium where only two candidates receive all the votes and the votes obtained by the third and following candidates approximate zero, is reached only over a series of elections (Gaines 1999), because the degree of coordination failure (i.e. wasted votes at district level) can be strengthened by new electoral rules or the entry of new parties (especially in new democracies). (Crisp et al. 2012) Finally, another interesting area for future research would be to determine several relatively heterogeneous regional patterns of competitiveness (as identified by the Nagayama diagrams) along with the factors (or processes) underlying these inter-regional variations in form of electoral competition.

Similarly, only repeated elections under the same electoral system can support or reject Tavits and Annus's (2006) 'learning hypothesis' that strategic voting in new democracies of Central and Eastern Europe tends to increase as voters (but also political elites) become more experienced with the electoral process. Here, more detailed evidence on the development of strategic voting in the elections of presidents of regional parliaments during 2001 and 2013 under the TRS are needed, which could confirm whether the stronger presence of ENEP values indicating two-party competition in 2013 (compared to 2017) was an exception, or more the result of a "learning" process realized in consecutive elections under the same electoral system.

However, the second-order character of Slovak regional elections leads us to hypothesize that even in the future, the elections of presidents of Slovak selfgoverning regions would not be able to fully meet the expectations of strategic voting based on the Duvergerian logic. Finally, an extension of the study to other countries (new as well as established democracies), where regional presidents (or governors) are also elected by direct vote, could confirm or reject whether the significant exceptions to Duverger's law and expectations of strategic voting are typical of most second-order elections, or whether the Slovak case is a significant exception compared to other countries.

Pavel Maškarinec is assistant professor at the Department of Political Science and Philosophy, Faculty of Arts, Jan Evangelista Purkyně University in Ústí nad Labem. He specializes on electoral geography, spatial analysis of elections, political participation and representation, quantitative research of 
electoral behaviour and electoral systems, and he also studies the ways party systems are shaped by these phenomena.

\section{REFERENCES}

ALBESCU, A.-M. - IONIȚĂ, D.-I. - MATEESCU, S.-D., 2012: Strategic Voting at the Romanian 2008 Local Elections. Mediterranean Journal of Social Sciences 3 (1): 297311. https://doi.org/10.5901/mjss.2012.03.01.297

BENKOVIČOVÁ, L., 2006: Pohl'ad na vybrané otázky volieb do samosprávnych orgánov vyšších územných celkov v roku 2005. Slovenská politologická revue 6 (4): 1-30.

BENOIT, K., 2006: Duverger's Law and the Study of Electoral Systems. French Politics 4 (1): 69-83. https://doi.org/10.1057/palgrave.fp.8200092

BLAIS, A., 2004: Strategic Voting in the 2002 French Presidential Election. In: LewisBeck, M. S. (ed.): The French Voter. London: Palgrave Macmillan, pp. 93-109. https://doi.org/10.1057/9780230523791

BUČEK, J., 2011: Building of Regional Self-Government in Slovakia: The First Decade. Geografický časopis 63 (1): 3-27.

BUČEK, J. - PLEŠIVČÁK, M., 2017: Self-Government, Development and Political Extremism at the Regional Level: A Case Study from the Banská Bystrica Region in Slovakia. Sociológia 49 (6): 599-635.

CHHIBBER, P. - KOLLMAN, K., 2004: The Formation of National Party Systems: Federalism and Party Competition in Canada, Great Britain, India, and the United States. Princeton: Princeton University Press.

CLARK, W. R. - GOLDER, M., 2006: Rehabilitating Duverger's Theory: Testing the Mechanical and Strategic Modifying Effects of Electoral Laws. Comparative Political Studies 39 (6): 679-708. https://doi.org/.10.1177/0010414005278420

COX, G. W., 1997: Making Votes Count: Strategic Coordination in the World's Electoral Systems. Cambridge: Cambridge University Press.

COX, G. W., 2001: Comment on 'Japan's Multimember SNTV System and Strategic Voting: The ' $M+1$ ' Rule and Beyond'. Japanese Journal of Political Science 2 (2): 237-239. https://doi.org/10.1017/S146810990100024X

CRISP, B. F. - OLIVELLA, S. - POTTER, J. D., 2012: Electoral Contexts that Impede Voter Coordination. Electoral Studies 31 (1): 143-158. https://doi.org/10.1016/j.electstud.2011.09.006

DIWAKAR, R., 2007: Duverger's Law and the Size of the Indian Party System. Party Politics 13 (5): 539-561, https://doi.org/10.1016/j.electstud.2011.09.006

DOLNÝ, B., 2014: Výsledky volieb do zastupitel'stva Bratislavského samosprávneho kraja 2013: Neúspech Smeru-SD ako trest voličov alebo volebného systému? Slovak Journal of Public Policy and Public Administration 1 (2): 101-119.

DOWNS, A., 1957: An Economic Theory of Democracy. New York: Harper \& Row.

DUNLEAVY, P. - DIWAKAR, R., 2011: Analysing Multiparty Competition in Plurality Rule Elections. Party Politics 19 (6): 855-886. https://doi.org/10.1177/1354068811411026

ĎURINOVÁ, P. - MALOVÁ, D., 2017: Gender Issues in Kotleba's People's Party of Our Slovakia: An Attempt at a Thematic Analysis. Human Affairs 27 (1): 59-74. https://doi.org/10.1515/humaff-2017-0006

DUVERGER, M., 1954: Political Parties. Their Organisation and Activity in the Modern State. London: Methuen.

Sociológia 50, 2018, No. 6 
FEŞNIC, F. N. - ARMEANU, O. I., 2014: Strategic Effects of Electoral Rules: Testing the Impact of the 2008 Electoral Reform in Romania. Studia Politica: Romanian Political Science Review 14 (2): 185-199.

GAINES, B. J., 1999: Duverger's Law and the Meaning of Canadian Exceptionalism. Comparative Political Studies 32 (7): 835-861. https://doi.org/10.1177/0010414099032007004

GREGOR, K., 2015: Who are Kotleba's Voters? Voters' Transition in the Banská Bystrica Region in 2009 - 2014. Sociológia 47 (3): 235-252.

GROFMAN, B., 1999: Preface: Methodological steps toward the study of embedded institutions. In: Grofman, B. - Lee, S.-C. - Winckler, E.A. et al. (eds.): Elections in Japan, Korea, and Taiwan under the Single Non-Transferable Vote: The Comparative Study of an Embedded Institution. Ann Arbor, MI: University of Michigan Press, pp. IX-XVII. https://doi.org/10.3998/mpub.15603.

GROFMAN, B. - BOWLER, S. - BLAIS, A., 2009: Introduction: Evidence for Duverger's law from four countries. In: Grofman, B. - Blais, A. - Bowler, S. (eds.): Duverger's Law of Plurality Voting: The Logic of Party Competition in Canada, India, the United Kingdom and the United States. New York: Springer, pp. 1-12. https://doi.org/10.1007/978-0-387-09720-6

Grofman, B. - Chiaramonte, A. - D'Alimonte, R. - Feld, S. L., 2004: Comparing and Contrasting the Uses of Two Graphical Tools for Displaying Patterns of Multiparty Competition: Nagayama Diagrams and Simplex Representation. Party Politics 10 (3): 273-299. https://doi.org/10.1177/1354068804042459

HÁJEK, L., 2015: Strategické hlasování prri volbách do Senátu PČR. Evropská volební studia 10 (1): 3-13.

HRUŠOVSKÝ, M., 2015: Vývojové tendencie regionálných volieb na príklade oravských volebných obvodov. Slovak Journal of Public Policy and Public Administration 2 (2): 167-186.

CHARVÁT, J., 2009: Úvahy nad otázkou platnosti Duvergerových hypotéz. Slovenská politologická revue 9 (2): 96-106.

CHYTILEK, R., 2007: Between the Macro and Micro Duvergerian Agendas. In: Strmiska, M. - Chytilek, R. - Hynek, N. (eds.): Federalism and Multi-level Polity: The Canadian Case. Brno: Anton Pasienka, pp. 33-68.

CHYTILEK, R - KUTNER, L., 2005: ElectMach, Election Software. http://www.ispo.fss.muni.cz/electmach-1 ?lang=

KARP, J. A., 2009: Candidate Effects and Spill-Over in Mixed Systems: Evidence from New Zealand. Electoral Studies 28 (1): 41-51. https://doi.org/10.1016/j.electstud.2008.06.012.

KARP, J. A. - VOWLES, J. - BANDUCCI, S. A. - DONOVAN, T., 2002: Strategic Voting, Party Activity, and Candidate Effects: Testing Explanations for Split Voting in New Zealand's New Mixed System. Electoral Studies 21 (1):1-22. https://doi.org/10.1016/S0261-3794(00)00031-7

KISS, A., 2015: Identifying Strategic Voting in Two-Round Elections. Electoral Studies 40: 127-135. https://doi.org/10.1016/j.electstud.2015.08.002

KLIMOVSKÝ, D., 2006: Regionálna samospráva v rokoch 2002 - 2005: Skúsenosti a súvislosti v politickej reflexii. In: Mesežnikov, G. (ed.): Regionálne vol'by 2005. Súvislosti a výsledky. Bratislava: IVO, pp. 29-56. 
KOVÁČOVÁ, E., 2018: Vol’by do orgánov samosprávnych krajov 2017. Analýza volebných výsledkov. Politické vedy 21 (1): 119-175. https://doi.org/10.24040/politickevedy.2018.21.1.119-175

KRIVÝ, V., 2002: Regionálne vol'by 2001 - analýza výsledkov. In: Mesežnikov, G. Nižňanský, V. (eds.): Reforma verejnej správy na Slovensku 1998 - 2002. Bratislava: IVO, pp. 201-249.

KRIVÝ, V., 2006: Výsledky regionálnych volieb 2005. In: Mesežnikov, G. (ed.): Regionálne vol'by 2005. Súvislosti a výsledky. Bratislava: IVO, pp. 107-182.

LAAKSO, M. - TAAGEPERA, R., 1979: Effective Number of Parties: A Measure with Application to West Europe. Comparative Political Studies 12 (1): 3-27. https://doi.org/10.1177/001041407901200101

MARUŠIAK, J., 2018: Krajské vol'by na Slovensku - nové preformátovanie slovenskej politickej scény. Contemporary European Studies 13 (1): 25-44.

MAŠKKARINEC, P., 2016: Strategic voting in the 2011 and 2015 Polish Senate elections: Testing Duverger's Law in the second-order elections. Slovak Journal of Political Science 16 (4): 369-391. https://doi.org/10.1515/sjps-2016-0018

MAŠKARINEC, P., 2017: Testing Duverger's law: strategic voting in Mongolian elections, 1996 - 2004. Post-Soviet Affairs 33 (2): 145-160. https://doi.org/10.1080/1060586X.2015.1119553

MAŠKKARINEC, P., 2018a: Strategic Voting in Hungarian Elections of 2014: Evidence for Duverger's Law under the Compensatory Mixed Electoral System? Studia Politica. Romanian Political Science Review 18 (1): 9-34.

MAŠKKARINEC, P., 2018b: The 2016 Electoral Reform in Mongolia: From Mixed System and Multiparty Competition to FPTP and One-Party Dominance. Journal of Asian and African Studies 53 (4): 511-531. https://doi.org/10.1177/0021909617698841

MAŠKARINEC, P. - BLÁHA, P., 2016: Křivda jako př́ležitost pro nové politické strany? Kotleba - Lidová strana Naše Slovensko na cestě parlamentu. Politics in Central Europe 12 (2S): 45-66.

MIKUŠ, R. - GURŇÁK, D. - MÁRIÁSSYOVÁ, A., 2016: Analýza volebnej podpory Mariána Kotlebu ako reprezentanta krajnej pravice v krajských vol'bách 2013. Sociológia 48 (1): 48-70.

MOSER, R. G. - SCHEINER, E., 2009: Strategic Voting in Established and New Democracies: Ticket Splitting in Mixed-Member Electoral Systems. Electoral Studies 28 (1): 51-61, https://doi.org/ 10.1016/j.electstud.2008.06.011

MOSER, R. G. - SCHEINER, E., 2012: Electoral Systems and Political Context: How the Effects of Rules Vary Across New and Established Democracies. Cambridge: Cambridge University Press.

NAXERA, V. - KRČÁL, P., 2016: Obrazy ne-bezpečnosti v projevech slovenských politiků. Politics in Central Europe 12 (1S): 49-61.

NIKOLENYI, C., 2004: Strategic Co-ordination in the 2002 Hungarian Election. EuropeAsia Studies 56 (7): 1041-1058, https://doi.org/10.1080/1465342042000294356

NOVÁK, M., 2015: Takzvané „,sociologické zákony“ Maurice Duvergera: jejich postupné formulování a jejich metodologické aspekty. Sociologický časopis 51 (1): 3-39. https://doi.org/10.13060/00380288.2015.51.1.152

PLEŠIVČÁK, M., 2017: Ideology, cleavages, and voting behaviour in 2009 and 2013 regional elections in Slovakia. AUC Geographica 52 (1): 100-115. https://doi.org/10.14712/23361980.2017.8 
RAE, D. W., 1971: The Political Consequences of Electoral Laws. New Haven, CT: Yale University Press.

RAYMOND, C. D., 2015: In Defiance of Duverger: The Class Cleavage and the Emergence of District-Level Multiparty Systems in Western Europe. Research and Politics 2 (1): 1-8. https://doi.org/10.1177/2053168014567557

RAYMOND, C. D. - HUELSHOFF, M. - ROSENBLUM, M. R., 2016: Electoral Systems, Ethnic Cleavages and Experience with Democracy. International Political Science Review 37 (4): 550-566, https://doi.org/10.1177/0192512115596368

REED, S. R., 1990: Structure and Behaviour: Extending Duverger's Law to the Japanese Case. British Journal of Political Science 20 (3): 335-356. https://doi.org/10.1017/S0007123400005871

REED, S. R., 2001: Duverger's Law is Working in Italy. Comparative Political Studies 34 (3): 312-327. https://doi.org/10.1177/0010414001034003004

REIF, K. - SCHMITT, H., 1980: Nine Second-Order National Elections - A Conceptual Framework for the Analysis of European Election Results. European Journal of Political Research 8 (1): 3-44. https://doi.org/10.1111/j.1475-6765.1980.tb00737.x

RIKER, W. H., 1982: The Two-Party System and Duverger's Law: An Essay on the History of Political Science. American Political Science Review 76 (4): 753-766. https://doi.org/10.1017/S0003055400189580

SCHAKEL, A. H., 2015: Nationalisation of Regional Elections in Central and Eastern Europe. East European Politics 31 (2): 229-247. https://doi.org/10.1080/21599165.2015.1036034

SHUGART, M. S., 2005: Comparative Electoral Systems Research. In: Gallagher, M. Mitchell, P. (eds.): The Politics of Electoral Systems. Oxford: Oxford University Press, pp. 25-55, https://doi.org/10.1093/0199257566.001.0001

SINGER, M. M., 2013: Was Duverger Correct? Single-Member District Election Outcomes in Fifty-three Countries. British Journal of Political Science 43 (1): 201-220, https://doi.org/10.1017/S0007123412000233

SINGER, M. M. - STEPHENSON, L. B., 2009: The Political Context and Duverger's Theory: Evidence at the District Level. Electoral Studies 28 (3): 480-491, https://doi.org/10.1016/j.electstud.2009.06.002

STATISTICAL Office of the Slovak Republic - Statistics (https://slovak.statistics.sk).

SPÁČ, P. - VODA, P. - ZAGRAPAN, J., 2016: Abeceda ako nástroj úspechu. Prípad regionálnych volieb na Slovensku. Sociológia 48 (1): 71-90.

TAAGEPERA, R., 2004: Extension of the Nagayama Triangle for Visualization of Party Strengths. Party Politics 10 (3): 301-306, https://doi.org/10.1177/1354068804042460

TAAGEPERA, R., 2007: Predicting Party Sizes: The Logic of Simple Electoral Systems. New York: Oxford University Press. https://doi.org/10.1093/acprof:oso/9780199287741.001.0001

TAAGEPERA, R. - SHUGART, M. S., 1989: Seats and Votes: The Effects and Determinants of Electoral Systems. New Haven, CT.: Yale University Press.

TAVITS, M. - ANNUS, T., 2006: Learning to Make Votes Count: The Role of Democratic Experience. Electoral Studies 25 (1): 72-90.

https://doi.org/10.1016/j.electstud.2005.02.003 